doi: $10.2306 /$ scienceasia1513-1874.2013.39.252

\title{
The effect of dietary sericin on rats
}

\author{
Waraporn Keawkorn $^{\mathrm{a}}$, Nanteetip Limpeanchob ${ }^{\mathrm{a}}$, Waree Tiyaboonchai ${ }^{\mathrm{b}}$, Sutatip Pongcharoen ${ }^{\mathrm{c}, *}$, \\ Manote Sutheerawattananonda ${ }^{\mathrm{d}}$ \\ ${ }^{a}$ Department of Pharmacy Practice, Faculty of Pharmaceutical Sciences, Naresuan University, \\ Phitsanulok 65000 Thailand \\ b Department of Pharmaceutical Technology, Faculty of Pharmaceutical Sciences, Naresuan University, \\ Phitsanulok 65000 Thailand \\ c Department of Medicine, Faculty of Medicine, Naresuan University, Phitsanulok 65000 Thailand \\ d School of Food Technology, Institute of Agricultural Technology, Suranaree University of Technology, \\ Nakhon Ratchasima 30000 Thailand
}

${ }^{*}$ Corresponding author, e-mail: sutatipp@nu.ac.th

Received 4 Dec 2012

Accepted 12 Mar 2013

\begin{abstract}
Dietary proteins have been reported to be beneficial for lipid metabolism, tissue growth, development, and repair, as well as immune response. The interactions of dietary proteins and their digested products may regulate the physiology and metabolism of the gastrointestinal tract. However, proteins are largely digested before reaching the large intestine. The present study investigated the use of the non-dietary protein, silk sericin, in rats. Rats were fed either with casein or sericin proteins. Their body weight, food consumption, and complete blood count were measured. The results showed that during the experimental periods, rats fed with casein and sericin diets had no significant changes on body weight, food consumption, or complete blood count. Sericin-fed rats had a significantly decreased CD8a and CD80 positive cells when compared with standard casein protein. In conclusion, dietary proteins may have a differential impact on the leukocyte profile. The mechanisms underlying these changes are not clear but they might be due to the different amino acid compositions of the proteins studied.
\end{abstract}

KEYWORDS: silk sericin, dietary proteins, systemic immunity

\section{INTRODUCTION}

Sericin is a natural macromolecular protein synthesized in the middle part of silk gland of silkworm, Bombyx mori. This protein consists of a group of polypeptides with molecular mass ranging from 20-400 kDa. Pharmacological activities of sericin includes anti-oxidant ${ }^{1}$, anti-coagulant ${ }^{2}$, anti-cancer activities $^{3-5}$, tyrosinase inhibition ${ }^{6}$, liver and gastric protection $^{7,8}$, as well as cholesterol lowering 9,10 . Sericin promotes wound healing process without causing inflammation ${ }^{11}$ and is widely used in tissue engineering ${ }^{12,13}$. In cell culture, sericin stimulates mitosis ${ }^{14}$, promotes cell proliferation ${ }^{15}$, protects against cell death ${ }^{16}$, and activates immune system ${ }^{6}$.

Evidence suggests that dietary proteins are necessary for regulation of immune system ${ }^{17}$. A deficiency of dietary protein or amino acids can cause impaired immune function and increase the susceptibility to infectious disease ${ }^{18}$. Thus there is growing interest in the role of amino acids in the immune function ${ }^{19}$. In particular, dietary whey proteins have the immunomodulatory effects in mice ${ }^{20}$. Like whey proteins, soy and casein enhance the immune system function $^{21,22}$. Soy protein contains some phytochemicals, such as isoflavones, which influence the signal transduction process of macrophages and cytotoxic $\mathrm{T}$ lymphocytes, thus influencing both non-specific and specific immune response ${ }^{23}$. Apart from dietary whey proteins, soy proteins and casein proteins can enhance immune response. Interestingly, sericin which is a non-dietary protein has been reported to activate immune system ${ }^{6}$. The immune system function can be divided into innate and adaptive immunity. The innate immune system acts as a first line of defence by preventing the entry of infectious agents or by eliminating invading pathogens ${ }^{24}$. Protection against infectious agents can be achieved by a combination of innate and adaptive immunity. Due to the complexity of the immune system, the effects of dietary proteins on the immune response is difficult to assess. To evaluate the possibility of using sericin as a dietary protein, the present research investigated the effects of dietary sericin in rats. 
Table 1 Amino acid composition of casein and sericin.

\begin{tabular}{lcc}
\hline Amino acid & \multicolumn{2}{c}{ Assay $(\mathrm{g} / 100 \mathrm{~g})$} \\
\cline { 2 - 3 } & Casein $^{\mathrm{a}}$ & Sericin $^{\mathrm{b}}$ \\
\hline Ser & 5.3 & 33.4 \\
Asp & 6.4 & 16.7 \\
Glu & 19.7 & 4.4 \\
Gly & 3.3 & 13.5 \\
Thr & 4.9 & 9.7 \\
Lys & 6.4 & 3.3 \\
Tyr & 4.1 & 2.6 \\
Arg & 2.6 & 3.1 \\
Ala & 4.6 & 6.0 \\
Val & 7.1 & 2.8 \\
His & 2.6 & 1.3 \\
Leu & 8.7 & 1.1 \\
Iso & - & 0.7 \\
Phe & 4.2 & 0.5 \\
Trp & - & 0.2 \\
Pro & 11.6 & 0.7 \\
Cys & 0.2 & 0.2 \\
Met & 2.6 & 0.04 \\
\hline a Based on Okazaki et al ${ }^{25}$. \\
\multicolumn{2}{c}{ based on Nantong Dongchang Chemical Industrial. }
\end{tabular}

Table 2 Experimental diets.

\begin{tabular}{lcc}
\hline Ingredients & \multicolumn{2}{c}{ Experimental diets $(\%)$} \\
\cline { 2 - 3 } & Casein & Sericin \\
\hline Casein & 4.0 & - \\
Sericin & - & 4.0 \\
Fat & 2.0 & 2.0 \\
Fibre & 2.0 & 2.0 \\
Crude protein & 12.0 & 12.0 \\
Basal diet mixture $^{\mathrm{a}}$ & 80.0 & 80.0 \\
\hline
\end{tabular}

${ }^{\text {a }}$ Based on standard rat diet CP082 (Perfect companion group co. Ltd, Bangkok).

\section{MATERIALS AND METHODS}

\section{Dietary proteins}

Casein and sericin diets were produced by the Institute of Agricultural Technology, Suranaree University of Technology, Nakhon Ratchasima, Thailand. Silk sericin was extracted with deionized water from raw silk yarns of silkworm Bombyx mori under high pressure and high temperature condition. The specific extraction condition is under a pending Thai patent (application number 080595 ). The protein extract was dried at $130^{\circ} \mathrm{C}$, grounded and sieved through $0.75 \mathrm{~mm}$ screen. Table 1 shows the amino acid compositions of casein and sericin determined by an amino acid analyser. Compositions of diet formulations are shown in Table 2. The experimental diets were prepared by mixing standard rat diet with casein or sericin at the level of $4 \% \mathrm{w} / \mathrm{w}$. All other chemicals used were of analytical grade and were purchased from Sigma Chemical Co. (St. Louis, MO, USA).

\section{Animals and experimental design}

Male Spargue-Dawley rats in the weight range of 120-160 g were obtained from National Laboratory Animal Centre, Mahidol University, Nakhon Pathom, Thailand. These rats were housed in stainless steel cages under hygienic conditions in the departmental animal house at room temperature of $24 \pm 2{ }^{\circ} \mathrm{C}$ and a humidity of $50 \pm 10 \%$ with a 12 h light-dark cycle. The experimental protocol was approved by the ethical committee for animal care of Naresuan University (protocol number 51040 022, approved on 14 October 2008). Before initiation of the experiments, rats were adapted to the laboratory condition for one week. After one week of acclimatization, the rats were randomized into two groups. Each group contained 6 rats. Briefly, one rat was taken from the cage and assigned to Group I, then another rat was taken and assigned to Group II, and continued alternating until each group had 6 rats. Rats in Group I were fed with casein diets and Group II were fed with sericin diets. The diet and water were provided ad libitum. Duration of the experiment was 20 weeks. Food consumption and body weight were recorded weekly throughout the experimental period. At the end of experiment, the rats were fasted overnight, anaesthetized with pentobarbitone sodium $(40 \mathrm{mg} / \mathrm{kg}$ body weight $)$ and then sacrificed. Blood samples were immediately collected with the use of heparin as anti-coagulant for immediate analysis of leukocyte subpopulations.

\section{Collection of blood and detection of surface markers}

Blood samples were obtained from these rats by cardiac puncture and were collected into two microcentrifuge tubes containing heparin sodium. Whole blood samples were stained with antibodies specific for CD2, CD3, CD4, CD8a, CD11a, CD25, CD45, CD54, CD80, and CD86 (all from Becton Dickinson, USA). After incubation with the antibodies, the blood samples were lysed with $2 \mathrm{ml}$ of $1 \times \mathrm{RBC}$ Lysis buffer (BioLegend) and the cells were added with $200 \mu \mathrm{l}$ of FACS buffer. All samples were analysed by FACS Calibur using CellQuestPro software (Becton Dickinson, USA).

\section{Statistical analysis}

The percentages of each cell type were obtained and the comparison between two groups was made using Student's $t$-test. The $p$ values of $<0.05$ were considered statistically significant. 
Table 3 Body weight and food consumption. Values are mean \pm SD.

\begin{tabular}{|c|c|c|c|c|c|}
\hline Treatment & $n$ & $\begin{array}{l}\text { Initial body } \\
\text { weight (g) }\end{array}$ & $\begin{array}{l}\text { Final body } \\
\text { weight }(\mathrm{g})\end{array}$ & $\begin{array}{l}\text { Body weight } \\
\text { gain }(\mathrm{g})\end{array}$ & $\begin{array}{l}\text { Food consumption } \\
(\mathrm{g} / \text { day })^{\mathrm{a}}\end{array}$ \\
\hline Group I Casein & 6 & $237 \pm 7$ & $503 \pm 28$ & $265 \pm 29$ & $18.2 \pm 0.9$ \\
\hline Group II Sericin & 6 & $235 \pm 28$ & $484 \pm 41$ & $254 \pm 18$ & $19.4 \pm 2.7$ \\
\hline
\end{tabular}

${ }^{\text {a }}$ Values from the last month of the experiment.

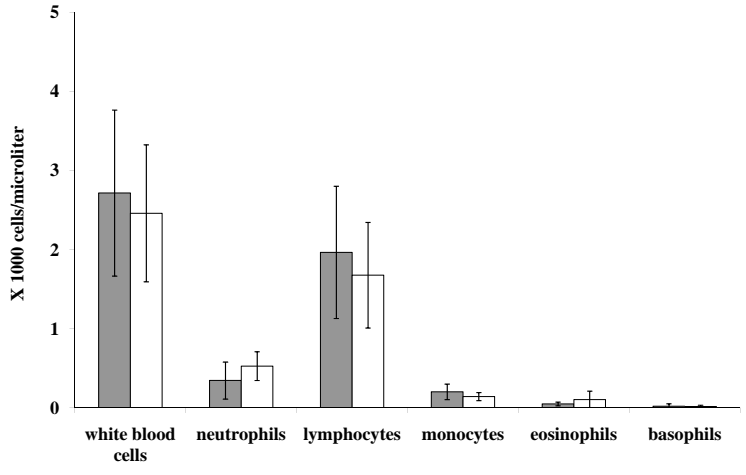

Fig. 1 Complete blood count of rats fed with casein (grey histogram) and sericin (white histogram). Bars are mean \pm SD.

\section{RESULTS}

\section{Effect of sericin on body weight and food consumption}

Table 3 presents the initial, final body weights, body weight gain and food consumption of casein-fed rats (Group I) and sericin-fed rats (Group II). The body weights and body weight gain of both casein and sericin diet were similar. No statistically significant difference was observed in food consumption between both groups of rats.

\section{Effect of sericin on complete blood count}

The average values of complete blood count of rats fed with casein and sericin diet are shown in Fig. 1. There was no change in complete blood count of the two groups of rats. These results also suggest that the type of protein (casein or sericin) has no effect on the pattern of these cells. The leukocyte profile of the rats was analysed based on cell surface markers on the peripheral blood leukocytes. Fig. 2 shows leukocyte subpopulations. There were similar percentages of the majority of leukocyte subpopulations in rats fed with casein and sericin diets. However, a significant reduction was found in CD8a positive cells and CD80 positive cells in the rats fed with sericin diet (Group II) as compared with casein diet group (Group I).

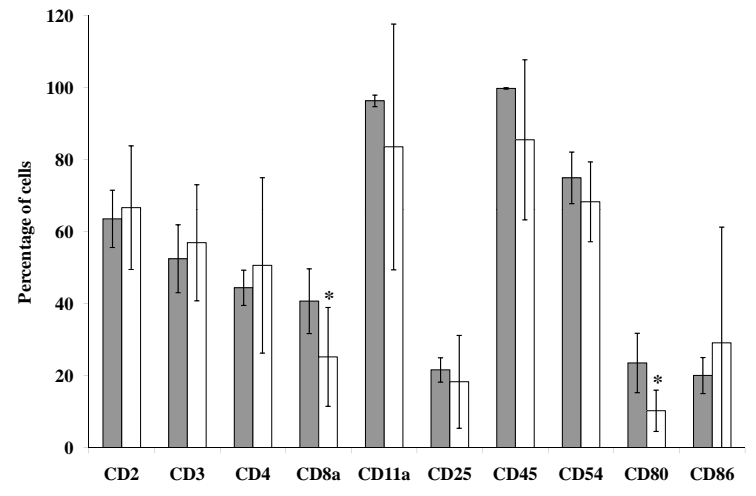

Fig. 2 Leukocyte subpopulations. Percentages of leukocyte subpopulations of rats fed with casein (grey histogram) and sericin (white histogram). ${ }^{*} p<0.05$ as compared with casein diet group. Bars are mean $\pm \mathrm{SD}$.

\section{DISCUSSION}

In this present study, rats fed with sericin diet had similar body weight and, by visual observation, the animals appeared to be in good health during the entire experimental period. Sericin has previously been shown to have anti-tumour effect, particularly in colon cancers $^{3-5}$. Sericin may enhance systemic immunity implicated in elimination of tumour cells. In the present study, however, the number of CD8a positive cells and CD80 positive cells decreased. CD8a is a surface marker of cytotoxic $\mathrm{T}$ cells and NK cells, which are responsible for immune response in elimination of tumour cells as well as viral infection ${ }^{24}$. Although there was a reduction in the percentages of CD8a positive cells, no significant alteration in CD4 positive cells was found. This suggests that sericin might have an effect on the function of cytotoxic $\mathrm{T}$ cells but it may not affect helper $\mathrm{T}$ cells. Despite the essential role of CD8 cell in anti-viral immunity, CD4 T cells can also play important roles for control of viral infection as well as cancer ${ }^{26,27}$. There was a reduction of $\mathrm{CD} 80$ positive cells without changes in CD86 positive cells. The co-stimulatory molecules such as B7-1 (CD80) and B7-2 (CD86) play an important role in the induction of $\mathrm{T}$ cell-mediated anti- 
tumour immunity ${ }^{28}$. It should be noted that rats in group I and II are normal rats, therefore it is difficult to draw a conclusion regarding the changes in these surface markers. However, the mechanism underlying the reduced CD8a positive and CD80 positive cells in the present study is unknown. It is possible that different amino acid compositions in these diets may have an impact on these alterations.

Casein protein and its fractions may enhance or suppress innate and adaptive immunity, depending on the purity of protein ${ }^{29}$. Purity of proteins has been considered to be involved in separation techniques. Although casein and sericin have mostly the same pattern of amino acids, sericin might have different immunomodulatory properties than that of casein. In addition, sericin has been shown to lower the level of inflammation in tissue engineering, making them a promising candidate in future biomedical applications ${ }^{6}$. Interestingly, sericin protein contains more serine, aspartic acid, and glycine than casein protein, amino acids reported to affect immune function ${ }^{25}$. Evidence suggest that glycine is essential for the proliferation and anti-oxidative defence of leucocytes and plays a role in regulating cytokine production and immune function ${ }^{30}$. In addition, aspartic acid is essential for the recycling of the citrulline produced by iNOS into arginine in activated macrophages. Thus aspartic acid contributes to the modulation of immune function $^{31,32}$. The role of dietary proteins on immune modulation, such as cytokine production, is complex and requires further investigations.

Acknowledgements: The authors received research grants for this work from the Thailand Research Fund (grant no. BRG 50800021), Faculty of Medicine, Naresuan University (grant no. MD-51-01-015), and Naresuan University (fiscal year 2010, grant no. R2553B030). The authors thank Ms Kwansuda Supalap, Ms Sanchawan Supalap, and $\mathrm{Mr}$ Seang Sriampai for their technical assistance.

\section{REFERENCES}

1. Kato N, Sato S, Yamanaka A, Yamada H, Fuwa N, Nomura M (1998) Silk protein, sericin, inhibits lipid peroxidation and tyrosinase activity. Biosci Biotechnol Biochem 62, 145-7.

2. Tamada Y, Sano M, Niwa K, Imai T, Yoshino G (2004) Sulfation of silk sericin and anticoagulant activity of sulfated sericin. J Biomater Sci Polymer Ed 15, 971-80.

3. Kaewkorn W, Limpeanchob N, Tiyaboonchai W, Pongcharoen S, Sutheerawattananonda M (2012) Effects of silk sericin on the proliferation and apoptosis of colon cancer cells. Biol Res 45, 45-50.
4. Zhaorigetu S, Sasaki M, Kato N (2007) Consumption of sericin suppresses colon oxidative stress and aberrant crypt foci in 1,2-dimethylhydrazine-treated rats by colon undigested sericin. J Nutr Sci Vitaminol 53, 297-300.

5. Zhaorigetu S, Sasaki M, Watanabe H, Kato N (2001) Supplemental silk protein, sericin, suppresses colon tumorigenesis in 1,2-dimethylhydrazine-treated mice by reducing oxidative stress and cell proliferation. Biosci Biotechnol Biochem 65, 2181-6.

6. Panilaitis B, Altman GH, Chen J, Jin H-J, Karageorgiou V, Kaplan DL (2003) Macrophage responses to silk. Biomaterials 24, 3079-85.

7. Li YG, Ji DF, Chen S, Hu GY (2008) Protective effects of sericin protein on alcohol-mediated liver damage in mice. Alcohol Alcohol 43, 246-53.

8. Li YG, Ji DF, Lin TB, Zhong S, Hu GY, Chen $S$ (2008) Protective effect of sericin peptide against alcohol-induced gastric injury in mice. Chin Med J 121, 2083-7.

9. Limpeanchob N, Trisat K, Duangjai A, Tiyaboonchai W, Pongcharoen S, Sutheerawattananonda M (2010) Sericin reduces serum cholesterol in rats and cholesterol uptake into Caco-2 cells. J Agr Food Chem 58, 12519-22.

10. Okazaki Y, Kakehi S, Xu Y, Tsujimoto K, Sasaki M, Ogawa H, Kato N (2010) Consumption of sericin reduces serum lipids, ameliorates glucose tolerance and elevates serum adiponectin in rats fed a high-fat diet. Biosci Biotechnol Biochem 74, 1534-8.

11. Aramwit P, Kanokpanont S, De-Eknamkul W, Srichana $\mathrm{T}$ (2009) Monitoring of inflammatory mediators induced by silk sericin. J Biosci Bioeng 107, 556-61.

12. Altman GH, Diaz F, Jakuba C, Calabro T, Horan RL, Chen J, Lu H Richmond J, Kaplan DL (2003) Silkbased biomaterials. Biomaterials 24, 401-16.

13. Mandal BB, Priya AS, Kundu SC (2009) Novel silk sericin/gelatin 3-D scaffolds and 2-D films: Fabrication and characterization for potential tissue engineering applications. Acta Biomaterialia 5, 3007-20.

14. Terada S, Sasaki M, Yanagihara K, Yamada H (2005) Preparation of silk protein sericin as mitogenic factor for better mammalian cell culture. J Biosci Bioeng $\mathbf{1 0 0}$, 667-71.

15. Terada S, Nishimura T, Sasaki M, Yamada H, Miki M (2002) Sericin, a protein derived from silkworms, accelerates the proliferation of several mammalian cell lines including a hybridoma. Cytotechnology 40, 3-12.

16. Takahashi M, Tsujimoto $\mathrm{K}$, Yamada H, Takagi $\mathrm{H}$, Nakamori S (2003) The silk protein, sericin, protects against cell death caused by acute serum deprivation in insect cell culture. Biotechnol Lett 25, 1805-9.

17. Ford JT, Wong CW, Colditz IG (2001) Effects of dietary protein types on immune responses and levels of infection with Eimeria vermiformis in mice. Immunol Cell Biol 79, 23-8.

18. Li P, Yin Y-L, Li D, Kim SW, Wu G (2007) Amino 
acids and immune function. Br J Nutr 98, 237-52.

19. Daly JM, Reynolds J, Sigal RK, Shou J, Libermann MD (1990) Effect of dietary protein and amino acid on immune function. Crit Care Med 18, S86-93.

20. Wong CW, Watson DL (1995) Immunomodulatory effects of dietary whey proteins in mice. J Dairy Res 62, 359-68.

21. Christensen HR, Brix S, Frokiaer H (2004) Immune response in mice to ingested soya protein: antibody production, oral tolerance and maternal transfer. $\mathrm{Br} J$ Nutr 91, 725-32.

22. Migliore-Samour D, Floc'h F, Jollès P (1989) Biologically active casein peptides implicated in immunomodulation. J Dairy Res 56, 357-62.

23. Rumsey GL, Siwicki AK, Anderson DP, Bowser PR (1994) Effect of soybean protein on serological response, non-specific defense mechanisms, growth, and protein utilization in rainbow trout. Vet Immunol Immunopathol 41, 323-39.

24. Janeway CA Jr (2001) How the immune system protects the host from infection. Microb Infect 3, 1167-71.

25. Okazaki Y, Tomotake H, Tsujimoto K, Sasaki M, Kato N (2011) Consumption of a resistant protein, sericin, elevates fecal immunoglobulin A, mucins, and cecal organic acids in rats fed a high-fat diet. J Nutr 141, 1975-81.

26. Nagy N, Ádori M, Rasul A, Heuts F, Salamon D, Ujvári D, Madapura HS, Leveau B, et al (2012) Soluble factors produced by activated $\mathrm{CD}^{+}{ }^{+} \mathrm{T}$ cells modulate EBV latency. Proc Natl Acad Sci USA 109, 1512-7.

27. Bassaganya-Riera J, Viladomiu M, Pedragosa M, De Simone C, Hontecillas R (2012) Immunoregulatory mechanisms underlying prevention of colitisassociated colorectal cancer by probiotic bacteria. PLOS ONE 7, e34676.

28. Ohtani H, Naito Y, Saito K, Nagura H (1997) Expression of costimulatory molecules B7-1 and B7-2 by macrophages along invasive margin of colon cancer: a possible antitumor immunity? Lab Investig 77, 231-41.

29. Wong CW, Seow HF, Liu AH, Husband AJ, Smithers GW, Watson DL (1996) Modulation of immune responses by bovine beta-casein. Immunol Cell Biol 74, 323-9.

30. Zhong Z, Wheeler MD, Li X, Froh M, Schemmer P, Yin M, Bunzendaul H, Bradford B, Lemasters JJ (2003) L-Glycine: a novel antiinflammatory, immunomodulatory, and cytoprotective agent. Curr Opin Clin Nutr Metab Care 6, 229-40.

31. Wu GY, Brosnan JT (1992) Macrophages can convert citrulline into arginine. Biochem J 281, 45-8.

32. Wu G, Flynn NE, Flynn SP, Jolly CA, Davis PK (1990)

Dietary protein or arginine deficiency impairs constitutive and inducible nitric oxide synthesis by young rats. J Nutr 129, 1347-54. 